\title{
TAMBUR PEH-CUN SEBAGAI IRINGAN LOMBA PERAHU NAGA DALAM UPACARA PEH-CUN DI TANGERANG BANTEN
}

\author{
Muhamad Solidio Gloryan Nasir \\ Jurusan Etnomusikologi FSP Institut Seni Indonesia Yogyakarta
}

\begin{abstract}
Abstrak
Masyarakat Cina Benteng yang mendiami daerah Tangerang Banten merupakan masyarakat yang memiliki adat istiadat seperti yang dilakukan oleh nenek moyangnya dari negeri Tiongkok. Tradisi yang merupakan warisan dari generasi yang terdahulu sampai saat ini tetap di laksanakannya yaitu upacara Peh-Cun dengan sangat meriah dan disesuaikan dengan tradisi nenek moyangnya. Pesta tersebut dilakukan dari prosesi ritual sampai dengan hiburan yang berupa lomba balap perahu naga. Hal ini yang menjadi suatu daya tarik dalam melakukan sebuah penelitian tentang obyek tersebut.

Penelitian mempergunakan metode kualitatif. Observasi secara langsung dilakukan untuk memahami beberapa fenomena yang ada dalam perayaan upacara tersebut dengan mengambil data di lapangan dan wawancara.

Hasil penelitian ini terdiri dari dua aspek, pertama, wujud ketaatan dan kesetiaan masyarakat Cina Benteng terhadap Tian (Tuhan) dan Khut Guan (tokoh legendaris dalam upacara Peh-Cun). Hasil yang kedua, perayaan Peh-Cun ini selain memberi hiburan kepada masyarkat, terdapat pula dorongan yang memberi semangat kepada masyarakat Cina Benteng. Hal itu terlihat ketika lomba balap perahu naga yang diiringi tambur pehcun dan gembreng dapat direspon oleh peserta lomba. Apabila fenomena musikal tersebut ditarik ke dalam ranah yang lebih luas, lomba balap perahu naga tersebut dapat memotivasi masyarakat etnis Cina Benteng untuk tetap kuat dan tegar dalam menjalani kehidupan yakni terwujudnya keseimbangan, seperti yang terdapat dalam konsep YinYang yang mereka yakini.
\end{abstract}

Kata Kunci: Tambur Peh-Cun, Masyarakat Cina Benteng, Lomba Balap Perahu Naga

\begin{abstract}
The Chinese Benteng community which inhabits the Tangerang Banten area is a community that has customs as practiced by its ancestors from China. The tradition he lived is the Peh-Cun ceremony. The party was carried out from ritual processions to entertainment in the form of dragon boat racing competitions. This is an attraction in conducting a study of the object.

The research uses qualitative methods. Direct observations are made to understand some of the phenomena that exist during the ceremony by taking data in the field and interviews.

The results of this study consisted of two aspects, first, the manifestation of the obedience and loyalty of the Chinese Benteng community towards Tian (God) and Khut
\end{abstract}


Guan (the legendary figure in the Peh-Cun ceremony). The second result, the Peh-Cun celebration besides providing entertainment to the community, there was also an encouragement that encouraged the people of Chinese Benteng. It was seen when the dragon boat racing competition accompanied by drummers and shouts could be responded by the contest participants. If the musical phenomenon is drawn into a broader realm, the dragon boat race can motivate the Chinese Benteng ethnic community to remain strong and firm in their lives, namely the realization of balance, as found in the Yin-Yang concept that they believe in.

Keywords: Peh-Cun Tambur, Chinese benteng community, Dragon Boat Race Competition

\section{Pendahuluan}

Masyarakat etnis Cina Benteng eksodus dari tanah leluhurnya karena peperangan yang tak kunjung berhenti sehingga mereka pergi tanpa persiapan apapun, seperti harta benda, berbagai bekal lainnya, dan terutama aspek pendidikan. Sesampainya mereka di tempat tujuan, biasanya bekerja serabutan, seperti sebagai petani, buruh, perajin, dan sebagainya. Tinggal lama di tanah rantau dan tidak membawa anak ataupun istri menyebabkanterjadi perkawinan silang budaya dengan masyarakat lokalyang melahirkan anak keturunan yang dikemudian hari dikenal sebagai masyarakat Cina Benteng (sebutan masyarakat tionghoa yang berada di kota Tangerang).
Awalnya sebutan Cina Benteng itu disematkan kepada mereka, karena tempat tinggalnya berada di sekitar benteng VOC Batavia. Pada saat itu disekitar benteng, beberapa masyarakat rantau ditempatkan secara berkelompok oleh rezim Belanda, seperti masyarakat Melayu, Batak, Makasar dan sebagainya. Ketika pengelompokan berbagai etnis dilakukan oleh rezim Belanda, etnis Cina dalam satu komunitas yang dipisahkan dari etnis bumi putra dan hanya diperbolehkan bekerja dalam bidang swasta atau perdagangan saja, mereka merasa diperlakukan tidak adil, sebagai masyrakat yang dianak-tirikan sehingga terjadilah pemberontakan pada tahun 1740 yang dikenal dengan peristiwa geger pecinan (Daradjadi, 2017: 44). 
Awal kehadiran mereka yang tidak disenangi oleh orang Belanda dan ketika di tempat tinggal yang baru dianggap sebagai warga terpinggirkan sehingga berlanjut di zaman kemerdekaan yang tentu saja mereka kehilangan identitasnya sebagai warga negara. Ketiadaan identitas menyebabkan mereka tidak bisa berkerja, dan mengenyam pendidikan bagi anakanaknya. Hal ini yang menyebabkan mereka menjadi masyarakat yang terpinggirkan, termarjinalkan dengan jeratan kemiskinan yang turun temurun.

Namun demikian, karena masyarakat Cina seperti halnya masyarakat Timur lainnya yang selalu memegang kuat tradisi, kepercayaan dan keyakinannya, maka dalam kehidupan yang sulit pun mereka tetap berpegang teguh pada hal-hal tersebut diatas. Itulah sebabnya berbagai kegiatan ritual dan upacara masih tetap eksis dan dilestarikan oleh masyarakat etnis Cina Benteng. Salah satu dari kegiatan upacara tersebut adalah upacara Peh-cun. Dalam rangkaian upacara Peh-cun salah satu acara yang dilaksanakan adalah lomba balap perahu naga. selain perahu naga adalah juga perahu pakpak yang digunakan oleh peserta lomba. Dalam hal ini, peneliti melihat bahwa didalam setiap perahu yang di gunakan oleh peserta lomba, mereka menggunakan tiga elemen musikal, yakni tambur Peh-cun, alat musik gembreng dan pemberi abaaba (dirigen). Hal itu menjadi daya tarik dan keunikan tersendiri bagi peserta maupun penonton yang melihat fenomena ini. Oleh sebab itu, dalam kesempatan ini peneliti ingin mengungkap keterkaitan aspek musikal dengan konteks sosial-budaya masyarakat etnis Cina Benteng.

\section{Schater and Singer}

Schacter dan Singer memberikan penjelasan tentang two factor theory of emotion. Emosi merupakan fungsi interaksi antara faktor kognitif dengan keadaan keterbangkitan fisiologis, setiap pengalaman yang membangkitkan emosi aka diberi labellabel dalam peta kognitif. Label-label tersebut dijadikan pola bagi pengalamanpengalaman baru dimana setiap stimulus yang diterima akan dinilai berdasarkan label yang tersimpan dalam dua faktor: 
1. Perubahan fisiologis

Stimulus seperti epinerphine yang dipergunakan dalam menginjeksi respon fisiologis partisipan mampu menyebabkan perubahan fisiologis seperti aliran darah pada otot dan meningkatkan tingkat detak jantung. Perubahan fisiologis adalah bagaimana individu dapat menjelaskan keadaan yang dapat menggambarkan sebuah keterangan yang membangkitkan emosi, kemudian menjelaskan tentang reaksi dan kesulitan dalam menghadapi situsi tersebut.

\section{Intepretasi kognitif}

Informasi yang diterima individu dan pengalaman masa lampau merupakan memori yang tersimpan dalam otak dan persepsi untuk mengintepretasikan perasaannya, secara sederhana Schahter dan Singer memberikan alur logika seperti di bawah ini:

Stimulus $\longrightarrow \quad$ Fisiologis $\longrightarrow$ Persepsi/Intepretasi (emosi subyektif)
Konsep Schachter dan Singer (1962) memberikan gambaran tentang pentingnya stimulus atau aksi yang menentukan respon fisiologis dan tingkat persepsi yang dialami subyek. Posisi yang cukup penting inilah yang menjadikan stimulus mempunyai nilai tawar sebagai aksi yang dipergunakan sebagai obyek yang menyebabkan lahirnya reaksi.

\section{Metode Penelitian}

Desain penelitian menggunakan kualitatif naratif. Menurut Creswell (2012) bahwa penelitian kualitatif naratif dalam menerapkan metode pengumpulan datanya menggunakan pertanyaan atau wawancara dan obervasi dengan analisis data berupa relasi semantik domain

\section{Hasil dan Pembahasan}

\section{Masyarakat Cina Benteng di Tangerang}

Cina Benteng bermukim di seberang timur sungai Cisadane.Tempat ini dikenal sebagai kota benteng, sebutan tersebut mengacu pada banyaknya sisa- 
sisa bangunan benteng peninggalan kolonial Belanda pada abad ke-17 (H.S Suhaedi,dan Ade Fakih Kurniawan dan Dedi Sunardi, 2015:77).

Selain benteng, berjajar pula bangker-bangker disepanjang kampung Babakan, sampai dengan pasar lama Tangerang.Sebutan Cina Benteng tersebut didasarkan pada tempat tinggal mereka, yakni disekitar benteng peninggalan kolonial Belanda. Selain sebutan atas dasar tempat, sebutan tersebut juga dikenakan kepada Etnis Cina peranakan yang tinggal di sekitar benteng Makasar yang saat ini berada di wilayah pasar lama Tangerang. Dengan bergesernya waktu, saat ini sebutan Cina Benteng juga disematkan kepada etnis Cina diseluruh wilayah kabupaten Tangerang, seperti: di desa Sewan, Kedawung Wetan maupun Selapajang.

Berdasarkan

pemerintahan zaman kolonial, pemerintahan Orde Lama, sampai dengan pemerintahan Orde Baru yang diskriminatif tersebut di atas, mengakibatkan banyak warga negara keturunan etnis Cina yang menetap di Tangerang yang dikenal dengan Cina Benteng tidak memiliki status kewarganegaraan yang jelas/stateless (Edi Purwanto, 2012: 428).

Kebijakan diskriminatif setiap pemerintahan yang berkuasa, ditambah birokrat yang korup menyebabkan warga keturunan etnis Cina enggan untuk mengurus dokumen-dokumen kewarganegaraannya. Dengan tidak adanya status kewarganegaraan maka mereka tidak mempunyai KTP, Akte kelahiran, maupun dokumen kelengkapannya. Akibat ketiadaan dokumen otomatis mereka kehilangan kesempatan kerja, baik di instansi pemerintah maupun swasta, kehilangan kesempatan pendidikan, akibatnya mereka menjadi warga yang terpinggirkan, menjadi warga minoritas. Keberlangsungan hidup etnis Cina, satusatunya jalan adalah berwirausaha, seperti mengolah pertanian, peternakan, industri rumahan seperti pembuatan arak, pembuataan gula, pembuatan batu bata, pertukangan, perdagangan, buruh pabrik, dan sebagainya.

Atas dasar berbagai uraian yang telah dipaparkan diatas maka masyarakat keturunan etnis Cina di seluruh Indonesia, dan khususnya masyarakat etnis Cina Benteng dapat melakukan 
berbagai hal seperti peribadatan di kelenteng, vihara, gereja, maupun masjid. Selain itu, bebas pula melestarikan dan mengembangkan adat dan tradisi leluhurnya, serta memperingati hari-hari besar Cina. Hal itu terjadi, ketika kebebasan telah dibuka seluas-luasnya ketika Abdurahman Wahid (Gus Dur) memimpin Negara Indonesia yang dikatakan oleh masyararakat Cina sebagai bapaknya etnis Cina Indonesia (Ibad. MN dan Akhmad Fikri AF, 2012: 155).

\section{Asal Mula Upacara Peh-cun}

Upacara Peh-cun pada dasarnya adalah hari raya yang diadakan untuk mengenang seorang tokoh legendaris dari negeri Cho yang bernama Khut Guan (di negeri Tiongkok). Ia adalah seorang menteri besar dan sekaligus sebagai tokoh pemersatu dari negara-negara tetangganya untuk menghadapi serangan dari negeri Chien yang agresif. Perjalanan hidupnya yang dilematis, yakni kecintaannya kepada bangsa dan tanah airnya disatu sisi, dan disisi lainnya karena fitnah dari lawan politik nya, Ia harus rela hidup dalam pengasingan.
Kehidupan Khut Guan di tempat pembuangan, yakni di tepi danau Tiong thing dekat sungai Bek lo dilaluinya bertahun-tahun dengan tenang dan tenteram. Namun demikian, kondisi dilematis dihadapinya lagi, ketika mendengar bio atau kelenteng tempat kelahirannya dihancurkan oleh tentara Chien. Disatu sisi ingin memanggul senjata karena kecintaannya pada bangsa dan tanah airnya, namun disisi lain dirinya sudah tua renta yang tidak mungkin lagi maju di medan laga. Akhirnya diputuskan, bahwa Ia akan menjadikan dirinya sebagai monumen atau tugu peringatan bagi seluruh masyarakat Cina. Ia mengorbankan dirinya sebagai penyemangat kepada masyarakat yang lemah, cinta kebenaran, dan cinta tanah air.

Hari Twan Yang adalah hari khusus persembahyangan untuk Tian (Tuhan), namun pada hari itu dipilihnya sebagai hari kematian Khut Guan dengan maksud untuk digunakan sebagai tonggak sejarah bagi seluruh rakyat negeri Cho.Setelah menyelesaikan sembahyang Twan Yang kemudian Khut Guan melanjutkan ritualnya dengan menyanyikan sajak ciptaannya yang 
berjudul Li sao (jatuh dalam kesukaran) yang disaksikan oleh masyarakat sekitar.Setelah pembacaan sajak selesai, kemudian Khut Guan membawa perahunya ke tengah sungai Bek Lo. Ketika perahunya sudah jauh dari kerumunan masa, Khut Guan mengikat tubuhnya dengan batu besar kemudian menceburkan dirinya di tengah sungai.

Persitiwa meninggalnya Khut Guan tersebut akhirnya diketahui oleh Gi $\mathrm{Hu}$, seseorang yang paling dekat dengan Khut Guan dalam kehidupannya di pengasingan yang berada di sekitar sungai Bek Lo. Pencarian Khut Guan oleh nelayan sekitar yang di pimpin oleh Gi $\mathrm{Hu}$ tidak membuahkan hasil, artinya Khut Guan tidak dapat di temukan jasadnya. Setahun kemudian, yakni pada tahun kedua meninggalnya Khut Guan, tepat di hari suci Twan Yang, sahabat setia Khut Guan, yakni Gi Hu pergi ke lokasi dimana Khut Guan menceburkan dirinya ke sungai Bek Lo. Kepergian Gi Hu ke lokasi meninggalnya Khut Guan tersebut bertujuan untuk mengenang kematian Khut Guan yang tidak lain adalah sahabatnya sendiri. Ketika pergi ke lokasi, Gi Hu membawa tempurung bambu yang berisi beras dan selanjutnya dilemparkan ke sungai. Hal itu dilakukan sebagai penghormatan dan mengenang kembali seorang tokoh yang sangat dihormati. Gerak langkah Gi Hu ditahuntahun berikutnya diikuti oleh masyarakat Cina sebagai acara tahunan yang dibingkai dan dikemas dalam lomba balap perahu, sebagai salah satu dari rangkaian upacara Peh-cun.

\section{Rangkaian Upacara Peh-cun}

Upacara Peh-Cun merupakan kegiatan yang dilakukan selama sehari semalam yang dibagi dalam dua sesi kegiatan, yaitu upacara pada malam hari dan upacara yang dilakukan pada siang hari. Di hari sebelum pelaksanaan upacara tersebut, terdapat salah satu kegiatan yang cukup menarik juga, yaitu acara pembakaran replika perahu naga. Kegiatan tersebut dilakukan pada siang hari juga dan bertempat di tengah sungai Cisadane.

Pada malam hari, acara utama adalah sembahyang malam yang ditujukan kepada Twan Yang dan dilanjutkan dengan doa memohon ijin kepada arwah leluhur untuk memandikan perahu yang dianggap keramat oleh masyarakat Cina Benteng. Untuk 
menunggu jam yang tepat pelaksanaan persembahyangan, yakni pada pukul 24.00 WIB, diisi dengan pementasan kesenian, seperti kesenian Barongsai dan kesenian Gambang Kromong.

Sementara kegiatan pada pagi hingga siang hari adalah sembahyang yang ditujukan kepada Twan Yang dan dilanjutkan dengan sembahyang yang ditujukan kepada Khut Guan. Setelah acara persembahyangan selesai, acara selanjutnya adalahacara tabur bunga di sungai, melempar kuecang dan melempar bacang ke sungai, mendirikan telur, melepas bebek ke sungai, dan diakhiri dengan lomba perahu naga.

\section{Lomba Balap Perahu Naga}

Lomba balap perahu, selain perahu naga juga perahu pakpak yang digunakan oleh peserta lomba. Perahu pakpak adalah perahu biasa tanpa hiasan, sementara perahu naga memakai hiasan naga. Kepala naga terletak didepan perahu, sedang tubuh dan ekor naga hanya berupa lukisan. Rangkaian lomba balap perahu naga terdiri dari tiga tahapan. Tahap pertama adalah persiapan, tahap kedua acara lomba, dan tahap ketiga adalah tahap perayaan kemenangan.

Dalam lomba balap perahu naga, pada setiap perahu yang di gunakan oleh peserta lomba menggunakan dua buah alat musik, yakni tambur Peh-cun dan gembreng dan selain itu juga ada seorang pemberi aba-aba (seperti dirigen). Untuk memperjelas instrumen musik tersebut perlu diutarakan pula tentang instrumen musik tersebut terlebih dahulu. Tambur Peh-cun adalah nama yang dipakai untuk menyebut alat musik perkusi tradisional dari negeri Cina. Tambur Peh-cun di negeri asalnya disebut dengan Cao gui. Suara yang dihasilkan dari instrumen musik ini berasal dari membran (terbuat dari kulit hewan) yang direntangkan pada benda berbentuk bulat terbuat dari kayu yang berfungsi sebagai ruang resonansi. Untuk menghasilkan bunyi, permukaan membran tersebut ditabuh dengan stik atau tongkat kayu sehingga menghasilkan bunyi dari alat musik ini. Jenis alat musik perkusi tersebut hingga saat ini tetap disebut sebagai tambur Peh-cun. Sementara kata Peh-cun dalam bahasa Hokian dapat diartikan 'mendayung perahu'. Dengan demikian definisi tambur Peh-cun adalah alat 
musik perkusi tradisional Cina yang digunakan dalam upacara Peh-Cun, baik sebagai iringan persembahyangan malam maupun untuk iringan dalam lomba balap perahu.

Instrumen perkusi telah lama dikenal oleh bangsa Cina. Berbagai varian'Cao gui' atau genderang, seperti: jiegu, yaogu, yиgu. Jiegu adalah genderang dengan satu permukaan yang ditabuh dengan stik atau alat pemukul untuk menghasilkan bunyi,sedangkan Yaogu adalah alat musik perkusi dengan dua permukaan (mirip kendang) yang dimainkan dengan alat pemukul juga, Lain halnya dengan Yugu. Alat musik ini, ruang resonansinya terbuat dari bambu dengan satu permukaan yang ditabuh dengan stik atau alat pemukul. Apabila ketiga waditra tersebut berfungsi untuk hiburan, lain halnya dengan Cao gui. Alat musik perkusi ini memiliki ukuran yang sangat besar. Waditra ini mirip dengan bedug yang sangat besar dan dengan cara dipukul untuk membunyikannya. Fungsi alat musik $\mathrm{Cao}$ gui adalah khusus untuk membangkitkan semangat prajurit ketika akan berperang. Penggunaan Cao gui ini diungkapkan ketika terjadi penyerangan pasukan dari negeri Qi melawan negeri (Lu Chunjiang $\mathrm{Fu}$, 2008: 53-59). Alat musik perkusi tersebut, yang mirip dengan tambur Pehcun adalah alat musik Cao gui. Perbedaan dari keduannya terletak pada ukuran dan cara menabuhnya. Kalau tambur Peh-cun ditabuh dengan posisi duduk, sedang Cao gui cara menabuhnya dengan posisi berdiri.

Waditra lain yang dikelompokkan dalam alat musik perkusi adalah luo. Alat musik ini dapat menghasilkan bunyi dengan cara ditabuh dengan stik atau alat pukul. Suara atau bunyi yang terdengar berasal dari tubuh benda itu sendiri. Alat musik ini juga terdaftar sebagai alat musik tradisional Cina. Luo terbuat dari lempengan besi dengan bentuk bulatan dan ditengahnya dibuat menonjol (pencon). Cara menabuhnya adalah dipukul pada bagian penconnya. Pada zaman kekaisaran Cina, alat musik ini selalu dipasangkan dengan alat musik Cao gui. Apabila Cao gui digunakan untuk membakar semangat prajurit menuju medan pertempuran, sementara alat musik luo dibunyikan sebagai tanda atau instruksi agar pasukan mundur dari medan pertempuran. Dalam upacara Pehcun dan dalam lomba balap perahu naga 
alat musik ini lazim disebut sebagai alat musik gembreng.

Dalam lomba balap perahu, perahu-perahu yang digunakan terdiri dari dua jenis, yakni perahu naga dan perahu pak-pak. Sementara kostum yang dikenakan warna-warni, dan setiap peserta pun tetap memakai baju pelampung. Perlu juga disampaikan, bahwa dalam lomba balap perahu tersebut terdiri dari tiga tahap.

\section{Tahap Persiapan}

Pada waktu kurang lebih pukul 13.00 WIB, tepatnya setelah semua rangkaian upacara selesai, masyarakat telah berkumpul di sepanjang sungai Cisadane, tak terkecuali para peserta yang akan ikut berlomba. Mereka berjajar memadati kiri-kanan sungai,sedangkan peserta lomba telah siap di atas perahunya masing-masing. Peserta lomba, dengan memakai kostum yang berbeda setiap kelompoknya dengan penuh harap dapat memenangkan perlombaan tersebut. Dalam setiap perahu tampak tiga orang menghadap kearah pendayung. Mereka adalah pemain tambur Peh-cun, penabuh gembreng, dan pemberi aba-aba, dalam setiap perahunya. Pada saat menanti pluit dari wasit, bunyi tambur dan gembreng pun mulai terdengar. Mereka memainkan pola ritme dengan tempo lambat, seperti transkripsi berikut:

\section{Pola I}
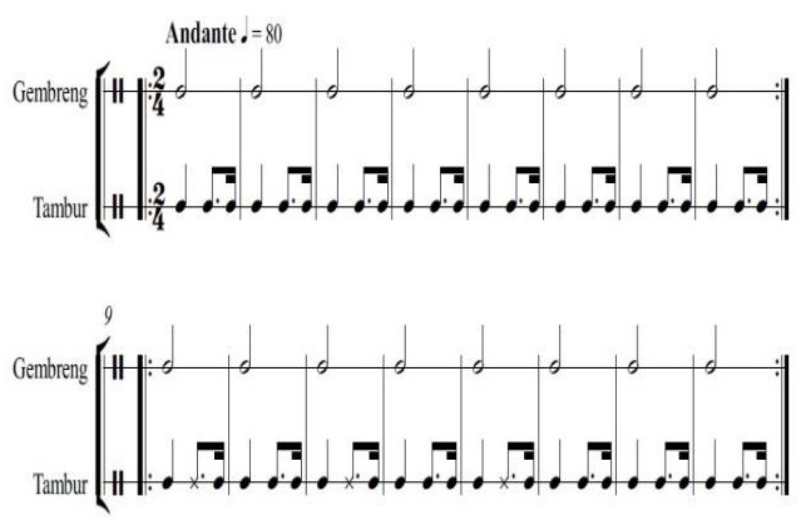

Pada tahap persiapan ini, para penserta standby dengan tetap mempertahankan posisi perahunya pada garis start, sehingga dengan tempolambat yang dimainkan oleh tambur dan gembreng membawa suasana yang tenang dan santai, walaupun para peserta tetap berkonsentrasi penuh.Artinya dalam suasana ini peran dari musik iringan adalah untuk membawa kontingen masing-masing peserta dalam kondisi tenang dan mempersiapkan energi. 


\section{Tahap Perlombaan}

Ketika suara pluit dari wasit terdengar, sebagai tanda dimulainya balap perahu, saat itu pula perahu-perahu peserta lomba mulai melaju dengan kencang. Bersamaan dengan hal itu suara tambur dan gembreng pun juga mulai riuh terdengar. Tidak kalah serunya ketika teriakan para suporter dari setiap kontingen dan juga para penonton yang menyaksikan lomba tersebut.Berpadunya antara musik iringan dari masing-masing perahu peserta dengan teriakan dan tepuk tangan penonton yang menyaksikan acara ini menjadi keindahan tersendiri.

Pola tabuhan yang dipakai untuk mengiringi tahap ini adalah berbeda dengan pola sebelumnya. Jika pola tabuhan yang pertama membawa peserta lomba untuk tenang dan mempersiapkan segala energi yang dimiliki para peserta, sebaliknya pada pola tabuhan yang kedua atau masyarakat setempat menyebutnya sebagai pola race, membawa peserta penuh energi dan semangat yang optimal. Pola race ini dimainkan dengan irama cepat seiring dengan kecepatan lajunya masing-masing perahu peserta lomba. Berikut adalah pola tabuhan dua atau pola race:
Pola II
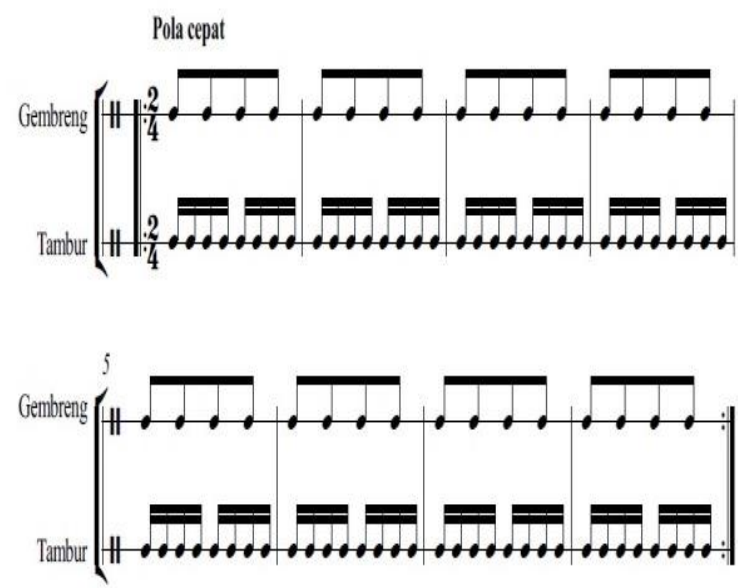

Tahap Kemenangan

Setelah perahu-perahu peserta lomba hampir mendekati garis finish yang telah ditentukan, kemeriahanpun tak terbendung lagi. Teriakan para suporter dari masing-masing kontingen dan juga tepuk tangan penonton yang menyaksikan lomba ini membuat suasana dalam acara ini begitu meriah.Namun demikian tiba-tiba suasana pun berubah drastis. Sekejap suasana hening ketika salah satu dari peserta lomba memasuki garis finish mendahului dari kontingen yang lain. Kemenangan dari salah satu kontingen tersebut membawa suasana berubah kembali, dengan penuh keceriaan dari pemenang disatu sisi dan tampak lemas dan muram dari peserta 
yang belum berhasil memenangkan lomba disisi lainnya. Akan tetapi suasana itu tidak berlangsung lama ketika suara musik iringan mulai terdengar kembali, tetapi hanya dari salah satu peserta lomba, yakni peserta yang memenangkan lomba tersebut. Pola tabuhan dari musik iringan inipun kembali berubah. Kondisi kontras terjadi dari musik iringan tersebut. Tempo yang dimainkan adalah 'sedang' dengan pola tabuhan tiga atau lazim disebut dengan pola tabuhan kemenangan.Pola tabuhan ini membawa suasana yang agung, sebagai tanda kemenangan yang disambut dengan tepuk tangan para penonton yang menyaksikan. Berikut adalah pola tiga atau pola kemenangan:

Pola III
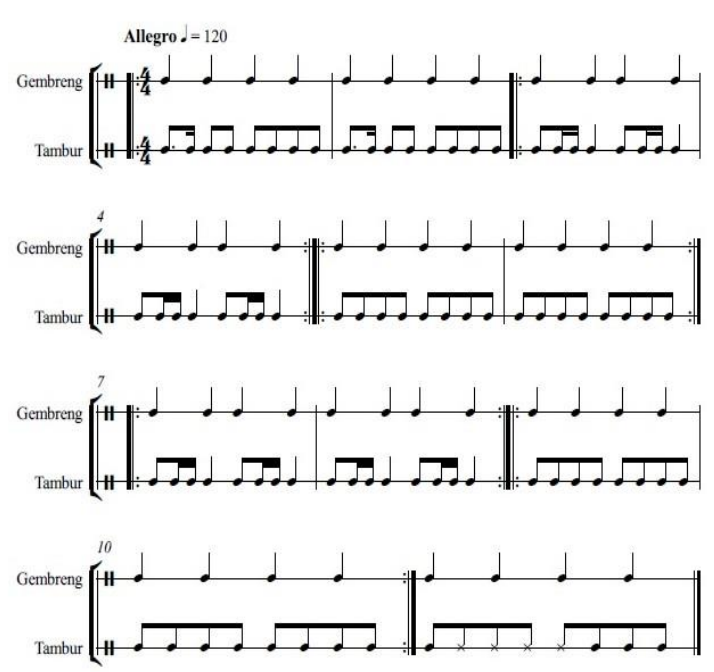

\section{Responsial Dalam Instrumen Tambur}

Musik merupakan pengungkapan gagasan melalui bunyi, yang unsur dasarnya berupa melodi, irama, dan harmoni (M. Soeharto, 1992:86). Memahami sebuah bentuk musik dan pengaruhnya terhadap orang yang mendengarkannya akan menimbulkan emosional yang bergejolak pada diri seseorang, sehingga dari bentuk emosional tersebut diaplikasikannya dalam bentuk tindakan.

Tidak dapat dipungkiri bahwa kebudayaan mempunyai pengaruh terhadap respon emosi, melalui musik sebagai stimulasi non-verbal. Masyarakat dengan budaya tertentu memiliki cara respons dan ekspresi yang berbeda pula. Kajian terhadap latarbelakang penciptaan music juga terkait erat dengan kondisi budaya dan aspek-aspek sosio psikologis yang ada di lingkup pencipta music pada tempat dan waktu tertentu (Djohan, 2009: 88).

Dalam psikologi umum dikatakan bahwa emosi proses spesifik yang berorientasi untuk merespon sebuah aksi. Emosi secara langsung selalu timbul baik terhadap sesuatu yang dianggap sebagai 
bagian dari situasi atau reaksi personal. Atribut khusus yang berkaitan dengan proses penilaian emosi adalah keterlibatan personal dengan stimulus dan terjadinya perubahan sesuatu terhadap stimulus itu (Frijda, 2009: 9194).

Instrumen Tambur dan Gembreng yang dimainkan dalam lomba balap perahu naga dalam pesta Peh-cun memegang peranan penting dalam memberikan semangat pada para pendayungnya. Diawali dengan perahu meluncur untuk persiapan dalam rangka perlombaan sampai dengan perahu mengakhiri lomba di garis finish. Kedua instrumen tersebut menjadi pemacu para pendayung dalam menjalankan perahunya dengan memperhatikan pola ritmis yang dimainkan oleh kedua instrumen itu.

Pendayung yang mendengarkan dengan seksama pola ritmis yang dimainkan merupakan rangkaian dalam tahapan sensasi.Sensasi yang dilakukan oleh pendayung berlanjut menjadi sebuah emosi. Melalui emosi inilah akan timbul suatu respon tubuh yang menggerakkan tangan pendayung sesuai dengan pola ritmisnya.

\section{Simpulan}

Masyarakat Cina Benteng berkembang dengan baik di kawasan kota Tangerang semenjak terusirnya dari kota Batavia pada tahun 1725 (sekarang Jakarta). Agama yang diyakini oleh masyarakat tersebut yaitu dengan memegang teguh agama Konghucu yang merupakan warisan dari budaya nenek moyangnya. Hal itu yang menguatkan persaudaraan diantara masyarakatnya dalam mengarungi kehidupannya. Salah satu budaya yang berkembang dalam masyarakat Cina Benteng adalah upacara Peh-cun.

Upacara peh cun merupakan manifestasi dari religiusitas masyarakat enis Cina, dan dalam hal ini masyarkat Cina Benteng yang terdiri dari dua aspek, yaitu aspek yang terkait dengan Tian dan yang kedua aspek yang terkait dengan tokoh legendaris Khut Guan. Aspek pertama adalah kegiatan persembahyangan kepada Tian yang bertepatan pada tangal 5 bulan 5 dalam kalender Imlek. Aspek yang kedua dilakukan berkaitan dengan peringatan wafatnya Kut Guan. Kedua hal tersebut menunjukan bahwa masyarakat Cina Benteng sebagai masyarakat yang 
meyakini tentang keberadaan Tian disatu sisi dan di sisi yang lain ketaatanya terhadap leluhur mereka.

\section{Salah satu dari Tridarma(} Sanjiao) di Klenteng Bon Tek Bio Tangerang, yakni ajaran Dao berkaitan dengan konteks budaya. Masyarakat Cina tidak mengenal alam yang jahat, namun sebaliknya ketidak seimbangan dari proses alam yang terganggu disebabkan oleh perbuatan dan ulah manusia itu sendiri. Hal tersebut tercermin dalam konsep Yin Yang. Konsep "Yin-Yang" pada dasarnya sangat sederhana, "Yin" merujuk ke bagian gelap dari alam semesta, sedangkan "Yang" merujuk pada bagian terangnya. Apabila hal ini dikaitkan dengan kehidupan masyarakat etnis Cina Benteng dapat dilihat seperti penggambaran dalam bab I, yakni disatu sisi tampak kehidupan yang glamour, yang dalam hal ini disebut sebagai konsep 'Yang" dan disisi lainnya sebuah kehidupan masyarakat yang sangat sederhana, yang terpinggirkan.

Kontradiktif dari kondisi demikian dapat dikatakan sebagai ketidak seimbangan dan jika dibiarkan berlarut-larut akan menimbulkan gejolak sosial yang signifikan. Oleh sebab itu, upacara Peh- cun diadakan dengan tujuan, yang pertama sebagai wujud kebaktian nya kepada Tian dan leluhur masyarakat etnis Cina Benteng, sedang tujuan yang kedua selain memberikan hiburan juga memberi dorongan dan semangat kepada masyarakat Cina Benteng untuk tidak patah semangat dalam mengarungi kehidupan, memperjuangkan hidup dan mensejahterakan keluarganya.

Upacara Peh-cun merupakan sebuah rangkaian proses pesta air yang dilaksanakan dengan dua tahapan yaitu pertama memandikan perahu dan yang kedua lomba balap perahu naga. Sebelum diadakan lomba perahu naga, dalam sebuah tempat khusus penyimpanan perahu yang diritualkan (pendapa Peh-cun) dilaksanakan memandikan perahu pada malam hari tepatnya pukul 24.00 WIB dengan melibatkan masyarakat Tionghoa. Masyarakat sangat antusias dengan acara tersebut karena meyakini akan mendapatkan berkah dalam mengikutinya. Setelah itu, esok harinya (pada siang hari) baru diadakan lomba perahu naga. Dalam rangkain upacara tersebut, alat musik tambur dan gembreng memegang peranan penting 
pada pelaksanaan lomba balap perahu karena berfungsi sebagai pemberi semangat dalam lomba tersebut.

Lomba balap perahu naga yang mempergunakan alat musik Tambur dan Gembreng memberikan nuansa kemeriahan dalam prosesi pesta PehCun. Kedua alat musik tersebut memberikan sentuhan sensasi dan emosi bagi para pendayung dalam menggerakkan perahu mereka untuk melaju lebih cepat sehingga bisa mendapatkan juara dalam balap itu. Hubungan responsial ini menjadikan suatu kesinambungan yang berarti antara musik dan manusia.

\section{Daftar Pustaka}

Creswell, Jhon. 2012. Research Design, Pendekatan Kualitatif, Kuantitatif dan Mixed terjemahan Achmad Fawaid: Pustaka Pelajar. Yogyakarta.

Daradjadi, 2017, Geger Pecinan 17401743 , Persekutuan Tionghoa Jawa Melawan VOC Jakarta : PT. Kompas Media Nusantara.
Djohan, 2009. Psikologi Musik, Yogyakarta: Best Publisher.

Fu Chunjiang, 2008, Origin Of Chinese Music: Asal Usul Musik Tionghoa, Jakarta: PT Elex Media.

Fikri, AF, Akhmad, dan MN, Ibad, 2012, Bapak Tionghoa Indonesia, Jakarta: PT. LKIS Printing Cemerlang.

Hasan, Ruqayah, dan Haliday, M.A.K, 1992, Bahasa, Konteks dan Teks: Aspek-Aspek Bahasa Dalam Pandangan Semiotika Sosial, Yogyakarta: Gadjahmada University Press.

Janz, Litza, dan Paul Cobley, Terj: Cipta Sungkono, 2002, Mengenal Semiotika For Beginners, Bandung: Penerbit Mizan.

Purwanto Edi, 2012, Kompleksitas Kemiskinan Tionghoa Benteng, Semarang: Program Pascasarjana Studi Universitas Kristen Satya Wacana.

Soeharto, M., 1992. Kamus Musik. Jakarta: Grasindo.

Sunardi, Dedi, Suhaedi, H.S, dan Kurniawan, Ade, Fakih, 2015, Etnis Cina Di Banten, Serang: LP2M IAIN SMH Banten. 